\title{
Regional differences in the frequency of diabetes occurrence and its treatment costs during the years 2008-2013, based on the NFZ (National Health Fund) database
}

Andrzej M. Śliwczyński ${ }^{1,2}$, Melania Brzozowska², Zbigniew Teter ${ }^{2}$, Michał Marczak ${ }^{3}$, Piotr Szymański ${ }^{4}$

\author{
${ }^{1}$ Public Health Department, Health Sciences Faculty, Medical University of Lodz, Lodz, \\ Poland \\ ${ }^{2}$ National Health Fund, Warsaw, Poland \\ ${ }^{3}$ Health Care Policy Department, Medical University of Lodz, Lodz, Poland \\ ${ }^{4}$ Institute of Cardiology, Warsaw, Poland
}

Submitted: 5 February 2015

Accepted: 4 June 2015

Arch Med Sci 2017; 13, 1: 256-259

DOI: 10.5114 /aoms.2016.64038

Copyright @ 2016 Termedia \& Banach

In the European region in 2013 the International Diabetes Federation (IDF) estimated the number of patients with diabetes at 56 million [1]. The costs of treatment in Europe were estimated at 140 million Euro. Recently Tamayo et al., when presenting the data for Poland in the updated IDF Diabetes Atlas report, estimated the morbidity at approx. 6.5\% [2]. This number was estimated based on the "Wieloośrodkowe Ogólnopolskie Badanie Stanu Zdrowia (WOBASZ)" project of 2003-2005 and earlier analyses from 1998-2001 [3]. Other studies include: Screen-Pol, Polish Multicenter Study on Diabetes Epidemiology (PMSDE) and "Nadciśnienie Tętnicze w Polsce Plus Zaburzenia Lipidowe i Cukrzyca (NATPOL-PLUS)" [4-6]. These analyses were partially local or were based on relatively small groups of patients. In 2004 the total cost of diabetes treatment in Poland was estimated at approx. PLN 6 billion [7]. High social costs of diabetes necessitate uninterrupted preventive activities, enabling the restriction of morbidity and public expenses for its treatment. The studies dedicated to regional variability of diabetes prevalence may help to identify specific risk factors and differences in management. In the region of Europe the differences of morbidity are very high, within the range from $2.4 \%$ in Moldavia up to $14.9 \%$ in Turkey [2]. In addition to the actual differences in the frequency of occurrence, they certainly are related to uneven and not fully reliable method of data calculation in individual countries [2]. Within Poland, the regional data concerning the frequency of diabetes occurrence in the years 2003-2005 ranged from $4.2 \%$ in women in Małopolska province up to $9.0 \%$ in men in Wielkopolska province [3]. Current data on regional differences may form the basis for future more detailed analyses on social, epidemiological and economic reasons for the variability of diabetes occurrence frequency in Poland.

The database of the National Health Fund enables the diabetes occurrence frequency assessment with unified methodology for the entire population of Poland divided by regions. This report presents the results of an abbreviated analysis of the general Polish NFZ (National Health Fund) database concerning the diabetes regional occurrence, based on the assessment of: (1) services provided according to ICD-10 codes:

\author{
Corresponding author: \\ Dr. Andrzej M. Śliwczyński \\ National Health Fund \\ 186 Grójecka St \\ 02-390 Warsaw, Poland \\ Phone: +48 604800718 \\ E-mail: andrzej.sliwczynski@ \\ nfz.gov.pl
}


E10 - insulin-dependent diabetes mellitus; E11 non-insulin-dependent diabetes mellitus; E12 malnutrition-related diabetes mellitus; E13 - other specified diabetes mellitus; E14 - unspecified diabetes mellitus; (2) filled prescriptions for oral diabetes medication, insulin and test strips for blood glucose meters. The patient population size (morbidity) along with territorial indicators was calculated using an anonymised individual patient number (PESEL). Morbidity indicators per 100,000 inhabitants of a given province were calculated based on demographic data obtained from the Chief Statistical Office website for each year separately.

In the years 2008-2013 each year on the average approx. 2.3 million patients were treated for diabetes (morbidity: 5.97\%). Small variations in the number of diabetes cases were observed between the years 2008 and 2009 as well as between 2011 and 2012. They may be attributed to the launch of the system and the legal changes introduced in 2011. There were no other significant differences in the number of diabetes volume in the subsequent years. In particular, no significant increase in diabetes prevalence was noted when years 2009 and 2013 were compared. Therefore based on the presented data it may be concluded that diabetes prevalence is in general stable in Poland. The regional morbidity indicators per 100,000 inhabitants in the years 2008-2013 sorted in descending order of frequency of occurrence in the year 2013 are presented in Table I, and the regional indicators of health care costs (total: services and medication and test strips for glucose meters) in Poland in the years 2008-2013 sorted in descending order, calculated per patient, are presented in Table II.

Average diabetes occurrence frequency in a given province in successive years of the studied period were not significantly statistically different (average 5,845 \pm 591 persons/100,000 inhabitants). However, the average diabetes occurrence frequency in the 8 provinces with the lowest morbidity indicators was statistically significantly lower than in the 8 provinces with the highest morbidity indicators $(6,454 \pm 335$ vs. $5,625 \pm 391$ patients per 100,000 province inhabitants; $p=0.002$; independent samples Student's $t$-test). The difference between the province with the highest (Śląskie) and lowest (Podkarpackie) morbidity was $14 \%$.

The average diabetes therapy cost per patient over the studied period was PLN $648 \pm 26$. There were statistically significant differences in the financing of diabetes therapy between the 8 provinces with the lowest and the 8 provinces with the highest cost of treatment (PLN per person 676.88 \pm 13.2 vs. $619.25 \pm 25.27 ; p<0.0001$; independent samples Student's $t$-test). The difference between the province with the highest (Podlaskie) and lowest (Dolnośląskie) average diabetes treatment cost was $8.5 \%$.

Table I. Average diabetes occurrence frequency in individual provinces in the years 2008-2013, calculated per 100,000 inhabitants, sorted in a descending order by frequency of occurrence for 2013

\begin{tabular}{|c|c|c|c|c|c|c|c|}
\hline Ranking & Province & 2008 & 2009 & 2010 & 2011 & 2012 & 2013 \\
\hline 1 & Śląskie & 6,609 & 7,203 & 7,483 & 7,798 & 6,759 & 7,062 \\
\hline 2 & Łódzkie & 6,055 & 6,846 & 7,165 & 7,801 & 6,733 & 6,919 \\
\hline 3 & Opolskie & 5,517 & 6,189 & 6,474 & 7,131 & 6,492 & 6,710 \\
\hline 4 & Dolnośląskie & 5,814 & 6,467 & 6,769 & 7,157 & 6,353 & 6,611 \\
\hline 5 & Zachodniopomorskie & 5,454 & 6,222 & 6,579 & 7,032 & 6,159 & 6,384 \\
\hline 6 & Pomorskie & 5,275 & 5,873 & 6,338 & 6,790 & 6,091 & 6,284 \\
\hline 7 & Kujawsko-pomorskie & 5,630 & 6,192 & 6,596 & 7,015 & 6,002 & 6,259 \\
\hline 8 & Świętokrzyskie & 5,515 & 6,093 & 6,403 & 6,852 & 5,910 & 6,128 \\
\hline 9 & Wielkopolskie & 5,294 & 5,887 & 6,184 & 6,568 & 5,841 & 6,088 \\
\hline 10 & Lubuskie & 4,883 & 5,389 & 5,701 & 6,149 & 5,728 & 6,053 \\
\hline 11 & Małopolskie & 5,564 & 5,933 & 6,173 & 6,609 & 5,655 & 5,878 \\
\hline 12 & Mazowieckie & 5,439 & 5,810 & 6,082 & 6,387 & 5,584 & 5,833 \\
\hline 13 & Lubelskie & 5,050 & 5,691 & 5,854 & 6,220 & 5,289 & 5,483 \\
\hline 14 & Warmińsko-mazurskie & 4,924 & 5,268 & 5,449 & 5,766 & 5,157 & 5,410 \\
\hline 15 & Podlaskie & 4,376 & 4,859 & 5,088 & 5,442 & 4,919 & 5,182 \\
\hline 16 & Podkarpackie & 4,463 & 5,100 & 5,324 & 5,670 & 4,897 & 5,074 \\
\hline
\end{tabular}


Table II. Average expenditures in PLN (Polish zlotys) in Poland calculated per patient (health care services) in individual provinces, in the years 2008-2013, sorted in descending order according to the amount of expenses for the year 2013

\begin{tabular}{|c|c|c|c|c|c|c|c|}
\hline Ranking & Province & 2008 & 2009 & 2010 & 2011 & 2012 & 2013 \\
\hline 1 & Podlaskie & 530 & 582 & 612 & 760 & 677 & 693 \\
\hline 2 & Lubuskie & 611 & 640 & 684 & 815 & 645 & 689 \\
\hline 3 & Śląskie & 530 & 575 & 598 & 764 & 659 & 687 \\
\hline 4 & Podkarpackie & 521 & 561 & 583 & 731 & 635 & 682 \\
\hline 5 & Małopolskie & 510 & 556 & 586 & 724 & 635 & 675 \\
\hline 6 & Mazowieckie & 489 & 548 & 595 & 734 & 657 & 669 \\
\hline 7 & Łódzkie & 490 & 557 & 587 & 732 & 620 & 665 \\
\hline 8 & Kujawsko-pomorskie & 517 & 571 & 623 & 759 & 608 & 655 \\
\hline 9 & Świętokrzyskie & 486 & 535 & 539 & 686 & 609 & 655 \\
\hline 10 & Wielkopolskie & 526 & 546 & 587 & 753 & 601 & 650 \\
\hline 11 & Lubelskie & 491 & 523 & 563 & 700 & 579 & 622 \\
\hline 12 & Pomorskie & 525 & 558 & 581 & 709 & 579 & 621 \\
\hline 13 & Opolskie & 525 & 558 & 600 & 706 & 579 & 617 \\
\hline 14 & Zachodniopomorskie & 489 & 535 & 569 & 710 & 574 & 613 \\
\hline 15 & Warmińsko-mazurskie & 451 & 518 & 560 & 688 & 566 & 599 \\
\hline 16 & Dolnośląskie & 476 & 490 & 526 & 673 & 542 & 577 \\
\hline
\end{tabular}

The presented results indicate significant variation both in the diabetes occurrence frequency indicators and diabetes treatment costs - interestingly, for different pairs of provinces. The WOBASZ analysis for the years 2003-2005 noted an even larger difference between the province with the highest diabetes occurrence frequency - up to $41.1 \%$ for men and $44.0 \%$ for women [3]. From the first 8 provinces with the highest diabetes occurrence frequency (for men) in the WOBASZ 2003-2005 study, the Śląskie, Opolskie, Zachodniopomorskie, Pomorskie and Kujawsko-pomorskie provinces remained in the top 8 . However, provinces where the diabetes occurrence frequency was previously relatively low - Świętokrzyskie, tódzkie and Dolnośląskie - have now moved to the top 8. tódzkie province is now in the second highest position, and Dolnośląskie province has moved from the last but one position to the fourth highest. In WOBASZ the highest morbidity was noted in Wielkopolskie province, where, according to the current analysis, morbidity is now moderate [3]. In the same province in WOBASZ the highest frequency of metabolic syndrome (in men) was also noted [8]. In the years 2003-2005 the frequency of metabolic syndrome in Śląskie province, which is now at the top position in diabetes prevalence, was relatively low [8]. On the other hand, in Łódzkie province, currently in second position, metabolic syndrome was relatively frequent [8]. These numbers clearly require further analyses, especially as the average anticipated lifespan is the shortest in tódzkie and significantly shorter than average in Śląskie province [9].

The highest diabetes treatment costs per patient were noted in Podlaskie province, where the diabetes occurrence frequency is rather low (last but one position in the ranking). Śląskie province has the highest morbidity and high treatment costs. Dolnośląskie province is in fourth position according to the prevalence of diabetes, but costs of treatment per capita are the lowest. Of note, 5 out of 8 provinces with the highest treatment costs are provinces with the lowest diabetes prevalence. This significant regional differences of diabetes prevalence and treatment costs require further analyses aimed at identifying the factors responsible for the presented variability. This will help to modify the local diabetes prevention and treatment programmes and to rationalise the expenses.

\section{Conflict of interest}

The authors declare no conflict of interest.

\section{References}

1. http://www.idf.org/diabetesatlas (Available at: 11.09.2014). 
2. Tamayo T, Rosenbauer J, Wild SH, et al. Diabetes in Europe: an update. Diabetes Res Clin Pract 2014; 103: 206-17.

3. Polakowska M, Piotrowski W. Incidence of diabetes in the Polish population: results of the Multicenter Polish Population Health Status Study--WOBASZ. Pol Arch Med Wewn 2011; 121: 156-63.

4. Grzeszczak W, Wójcikowski C, Sieradzki J, et al. ScreenPol III: early detection of type 2 diabetes mellitus observed during Polish Screen-Pol study. Regional differences [Polish]. Diabetol Pol 1999; 2: 187-208.

5. Szybiński Z. Polish Multicenter Study on Diabetes Epidemiology (PMSDE) - 1998-2002 [Polish]. Pol Arch Med Wewn 2001; 106: 751-65.

6. Zdrojewski T, Bandosz P, Szpakowski P, et al. Prevalence of main risk factors of cardiovascular system diseases in Poland. Results of the NATPOL PLUS study [Polish]. Kardiol Pol 2004; 61: 1-26.

7. Kinalska I, Niewada M, Głogowski C, et al. Koszty cukrzycy typu 2 w Polsce (Badanie CODIP). Diabetol Prakt 2004; 5: 1-8.

8. Wyrzykowski B, Zdrojewski T, Sygnowska E, et al. Epidemiologia zespołu metabolicznego w Polsce. Wyniki programu WOBASZ. Kardiol Pol 2005; 63 (Suppl 4): S1-4.

9. http://stat.gov.pl/obszary-tematyczne/ludnosc/trwanie-zycia/trwanie-zycia-w-2013-r-,2,8.html (Available at 27.09.2014). 